is no publication which shows the corresponding value in Greenwich mean time of the local time employed throughout the world. Such a table is much wanted, and is indispensable in order to determine the instant of occurrence of earthquakes, magnetic phenomena, \&c. - Sunless days and the day-distribution of sunshine in summer. This is a discussion of twenty years' observations at Greenwich (1877-96). About one-fourth of our days are sunless. Spring has an average of I2.I; summer, $64^{\circ}$; autumn, $25^{\circ} \mathrm{o}$; and winter, $48^{\circ} 5$ sunless days. The most "bright sunshine" occurs in May. During the five months May to September, 20 per cent. of the days have less than one hour's sunshine, while I4 per cent. have ten hours, or more. There are only eight cases of fourteen to fifteen hours' sunshine, and only one (in 1887) over fifteen hours.-Other papers refer to "so-called sulphur rains," "trees damaged by lightning," \&c.

\section{SOCIETIES AND ACADEMIES.}

\section{MANCHESTER.}

Literary and Philosophical Society, October 19.- $\mathrm{Mr}$. J. Cusmo Melvill, President, in the chair. - The death of Mr. James Heywood, F.R.S., the father of the Society, was announced, and a vote of condolence with the family was moved. - Prof. H. B. Dixon described experiments made in photographing explosion-flames : first, attempts made abroad, and afterwards experiments of his own.-Prof. F. E. Weiss exhibited some fiowering specimens of the Dog's Mercury, which usually flowers in spring; but the plant from which the shoots exhibited were collected has been observed by Mr. F. J. George, of Chorley, for thirteen successive seasons to flower in the autumn. Sir Joseph Hooker, to whom some of these shoots had been sent, was of the opinion that this plant might be regarded as a special form with this autumn flowering character. - A paper by Mr. P. Cameron, entitled "Notes on a collection of Hymenoptera from Greymouth, New Zealand, with descriptions of new species," was communicated by the President.-Mr. Melvill afterwards exhibited some specimens of Sisymbrium strictissimum, found by Mr. Henry Hyde on the banks of the Mersey at Stretford.

PARIS.

Academy of Sciences, October I8.-M. A. Chatin in the chair-O On the observation and kinematical interpretation of the phenomena discovered by Dr. Zeeman, by M. A. Cornu. The phenomenon in question, the formation of doublets and uriplets in a spectrum by the action of external magnetic for ces, is shown experimentally to be subject to the laws of Fresnel and Ampere. It differs essentially from the Faraday effect, in that the latter is produced upon luminous waves that have acquired a steady state, causing an alteration in the velocity of propagation, whilst in the Zeeman effect the magnetic action is exerted upon the source of the waves, and affects the period of vibration.-An account of the International Geological Congress at St. Petersburg, by M. Albert Gaudry. - On pencils and congruences, by M. Guichard. - Researches upon alcohol motors, by M. Max. Ringelmann. Two sets of trials were made, one upon a 3 h.p. horizontal, the other upon a 4 h.p. vertical oil engine. As the result of the trials it was found that the cost of alcohol, petroleum spirit, and ordinary burning oil were $5.625, I^{\cdot} 75$ and itoo respectively. - On the form of the lines of electric force in the neighbourhood of a Hertz resonator, by M. Gutton. The field was explored by means of a modification of the receiver of Prof. J. C. Bose.-Densities of some easily liquefiable gases, by M. A Leduc. The gases examined were carbon dioxide $\left(I_{5} 287\right)$, nitrous oxide $(\mathrm{I} \cdot 530 \mathrm{I})$, hydrogen sulphide (I.I895), chlorine $(2.49 \mathrm{I})$ and ammonia $(0.5971)$. - On the impurities of crude copper, by M. Schlagdenhauffen. Thin sheets of crude Chilian copper, left in contact with water for several days, gave up appreciable quantities of arsenious acid and oxide of antimony. From this experiment the conclusion is drawn that arsenic and antimony are present, at any rate in part, in the form of oxide in crude copper.-On the electric conductivity of trichloracetic acid, by M. Paul Rivals. Measurements of the conductivity and heat of solution of trichloracetic acid at different concentrations showed that the heat of dilution of this acid is a linear function of the fraction of dissociation. The heat of neutralisation by potash (N) calculated from Ostwald's formula, $\mathrm{N}=13.52+$ $(1-m) d$, where 13.52 is a constant common to both strong acids and strong bases, $m$ is the fraction of dissociation, and $d$ the

heat of dissociation, accorded rery closely with the experimentally determined values. - On the mean molecular weig't of the soluble material in germinating grains, by M. L. Maquenne. - General observations on oats, by M. Balland. An analytical table is given, showing the maximum and minimum values of the proximate constituents of oats.-New bile pigments, by MM. A. Dastre and N. Floresco. - Action of the X-rays on the heat radiated by the skin, by M. L Lecercle. Under the action of the $\mathrm{X}$-rays there is an increase in the radiation of heat from the skin, an increase which frequently persists for some time after the exposure.

\title{
BOOKS, PAMPHLETS, and SERIALS RECEIVED.
}

Books.-The Founders of Geology : Sir A. Geikie (Macmillan).-Papers printed to commemorate the Incorporation of the Universily College of Sheffield: The Winter Meteorology of Egypt, and its Intuence on Disease : Dr. H. E. L. Canney (Bailliere).-Chemistry for Photographers :
C. F. Townsend (Dawbarn).-Memorials of Wm. Cranch Bond and of his Son Geo. Phillips Bond: E. S. Holden (San Francisco, Murdock). - Life-Histories of American Insects : Prof. C. M. Weed (Macmillan),-Tracé d un Chemin de Fer: A. Dufour (Paris Gauthier-Villars).-Theoretical Mechanics: A. E H. Love (Cambridge University Press).-A Practical Physiology: Dr. A. F. Blaisdell (Boston, Ginn). - Ostwald's Klassiker der Exakten Wissenschaften, Nrs. 88-9r (Leipzig, Engelmann). -Nights w.th an Old Gunner: C. J. Cornish (Seeley).--Report of the Commissioner of Education for the Year 1895-96, Vol. I, Part I (Washington). - La Vie Mode de Mouvement : Prof. E. Préaubert (Paris, Alcan). - Wechselstrommessungen und Magnetische Messungen: Dr. C. Heinke (Leipzig. Hirzel). - Notes on Miiro. Organisms Pathogenic to Man: Surgeun-Captain B. H. S. Leumann (Longmans).

PAMPHLETS - Revision of the Tachinide of America North of Mexico D. W. Cofuillett (Washington). -Zur Psychologie des Erkennens : Dr. G.

Wolff (Leipzig, Engelmann).
SERIALS.-Physical Review, August (Macmillan)-Bibliotheca Georaphica herausgegeben von der Gesellschaft für Erdkunde zu Berlin, Band iii. Jahrg. ${ }_{1894}$ (Berlin).-Revue de l'Université de Bruxeiles, Band iii. Jahrg. ${ }^{1894}$ (Berlin).- Revue de Iniversite de Bruxeiles, October (Bruxelles). - Bulletin of the American Mathematical Society, October (New York). - Traité Encyclopédique de Photograpbie : Prof. C. Fabre, deux supplément, B, r. 2, 3 fasc. (Paris, Gauthier-Villars).- Journal of the Chemical Society, October (Gurney)-Quarterly Review, October (Murray).-Middlesex Hospital Journal, No. 4 (London).-Reliquary and zine, November (Longmans).

\section{CONTENTS.}

PAGE

The Logic of Darwin. By E. B. P. . . . . . . . . 609

A Theory of Physics . . . . . . . . . 6II Our Book Shelt :-

Noyes: "A Detailed Course of Qualitative Chemical Analysis of Inorganic Substances, with Explanatory Notes"

Deventer : "Physikalische Chemie für Anfänger" * 612

Pike: "Bromide Enlargements, and How to Make them" “The Machinery of the Universe: Mechanical Conceptions of Physical Phenomena" 612 Letters to the Editor:-

On the Meaning of Symbols in Applied Algebra. Prof, Oliver J. Lodge, F.R.S . . . . . 613

Strange Instinct of Fear in the Orang.-R. I. Pocock $6 \mathrm{I}_{3}$ Hereditary Colour in Horses. $-F$. Howard Collins 613 Dog Running on Two Legs. -F. M. Burton ... 613 The Observation of Meteors, with Especial Reference to the Leonids. By W. F. Denning . 613 The Klondike Placers. By Dr. T. K. Rose . . . 615 Notes ................ 616 Our Astronomical Column :-

Stars in the Large Magellanic Cloud . . . . . . . 620

The Photography of Delicate Celestial Phenomena . 620 Comet Perrine, October 16 . . . . . . . . . . 620

Dr. B. Engelhardt's Observatory . . . . 620 Science and Modern Civilisation. By Sir William Roberts, F.R.S. The Behaviour of Argon in X-Ray Tubes. By
Prof, H. L. Callendar, F.R.S., and N. N. Evans. The Origin of the European Fauna. By Dr. R. F. Scharf
Manchester's Report on Technical Education in Germany and Austria . . . . . . . . . 627 University and Educational Intelligence . . . . 630 Scientific Serials .......... 631 Societies and Academies ......... 632 Books, Pamphlets, and Serials Received . . . . $63^{2}$

$$
\text { NO. } 146 \mathrm{I} \text {, VOL. } 56]
$$

